\title{
CLAUDIA MAIENBORN
}

\section{ON DAVIDSONIAN AND KIMIAN STATES*}

Abstract. Davidsonian event semantics has an impressive track record as a framework for natural language analysis. In recent years it has become popular to assume that not only action verbs but predicates of all sorts have an additional event argument. Yet, this hypothesis is not without controversy in particular wrt the particularly challenging case of statives. Maienborn (2003a, 2004) argues that there is a need for distinguishing two kinds of states. While verbs such as sit, stand, sleep refer to eventualities in the sense of Davidson (= Davidsonian states), the states denoted by such stative verbs like know, weigh, and own, as well as any combination of copula plus predicate are of a different ontological type ( Kimian states). Against this background, the present study assesses the two main arguments that have been raised in favour of a Davidsonian approach for statives. These are the combination with certain manner adverbials and Parsons' (2000) so-called time travel argument. It will be argued that the manner data which, at first sight, seem to provide evidence for a Davidsonian approach to statives are better analysed as non-compositional reinterpretations triggered by the lack of a regular Davidsonian event argument. As for Parsons's time travel argument, it turns out that the original version does not supply the kind of support for the Davidsonian approach that Parsons supposed. However, properly adapted, the time suggested by the assumption of Kimian states.

\section{INTRODUCTION}

Hidden event arguments, as introduced by Davidson (1967), have proven to be of great benefit in explaining numerous combinatorial and inferential properties of natural language expressions. Probably the greatest benefit of the Davidsonian approach is its straightforward account of adverbial modification. If verbs introduce an event argument, as Davidson suggested, then adverbial modifiers can be analysed as simple first-order predicates that add information about this event.

The question that naturally arises, though, is whether Davidson's proposal, which was originally confined to action verbs, can be extended to other types of verbal predicates. While this seems to be uncontroversial for process verbs, the critical case is that of statives. Following Higginbotham $(1985,2000)$ and particularly Parsons $(1990,2000)$, scholars working in what has been called the neoDavidsonian paradigm assume that arbitrary verbal predicates - which, crucially, include statives - have an underlying Davidsonian event argument. ${ }^{1}$ This is illustrated by the following quotations from Higginbotham (1985) and Chierchia (1995)

The position $E$ corresponds to the 'hidden' argument place for events, originally suggested by Donald Davidson (1967). There seem to be strong arguments in favour of, change or action. Under this extension, statives will also have $E$-positions.

Higginbotham (1985: 10) 
A basic assumption I am making is that every $\mathrm{VP}$, whatever its internal structure and aspectual characteristics, has an extra argument position for eventualities, in the spirit of Davidson's proposal. [...] In a way, having this extra argument slot is part of what

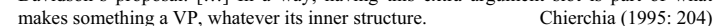

Despite its popularity, the claim that statives have a hidden event argument is seldom defended explicitly. Parsons $(1995,2000)$ is among the few advocates of the neo-Davidsonian approach who have subjected this assumption to some scrutiny. ${ }^{2}$ While Parsons himself does not consider previous evidence for an event-based analysis of statives to be particularly compelling, he does consider his so-called time travel argument (as developed in Parsons 2000) to make a strong case for such an analysis.

The aim of the present study is to assess Parsons' arguments for this analysis of stative expressions against the background of the theory developed in Maienborn (2003a, 2004), which rejects the Davidsonian approach for copula sentences. In that work, I argue for a distinction between two kinds of states: While Davidsonian states denoted by verbs such as sit, stand, sleep are eventualities in the sense of Davidson, the states denoted by such stative verbs like know, weigh, and own, as well as any combination of copula plus predicate do not qualify as Davidsonian eventualities but are instead what I call Kimian states. As I will show, Parsons' time travel argument turns out to support this distinction.

The paper is organised as follows. Section 2 provides a summary of my account of Davidsonian and Kimian states as two ontologically distinct categories whose members natural language expressions refer to. Section 3 discusses certain cases of manner modification which, at first sight, seem to provide evidence for a Davidsonian approach to statives but which are, in fact, better analysed as noncompositional reinterpretations triggered by the lack of a regular Davidsonian event argument. Section 4 is devoted to Parsons' time travel argument. While the original version does not supply the kind of support for the Davidsonian approach that Parsons supposed, I will propose a time travel variant showing that statives indeed call for a reification of their denotatum, as suggested by the assumption of Kimian states. Finally, section 5 explores some of the consequences of the Kimian approach advocated here and of its Davidsonian rivals.

\section{TWO KINDS OF STATES}

The theory developed in Maienborn (2003a, 2004) is based on the observation that there is a fundamental split within the class of non-dynamic expressions. State verbs such as sit, stand, lie, wait, gleam, and sleep meet all of the criteria for Davidsonian eventualities. ${ }^{4}$ In contrast, stative verbs like know, weigh, own, and resemble do not meet any of them. In particular, copular constructions, as we will see, behave uniformly like stative verbs regardless of whether the predicate denotes a temporary property (socalled "stage-level predicates") or a more or less permanent property (socalled "individual-level predicates"). ${ }^{5}$ The following subsection reviews the crucial eventuality tests and illustrates the distinct behaviour of the two classes of state expressions with respect to these tests. 
2.1. The Davidsonian approach

On the received view, Davidsonian eventualities are spatiotemporal entities, whose properties are summarized in the more or less standard working hypothesis given in (1).

(1) Davidsonian eventualities:

Eventualities are particular spatiotemporal entities with functionally integrated participants.

Several ontological properties follow from this definition:

(2) Ontological properties of eventualities

a. Eventualities are perceptible.

b. Eventualities can be located in space and time.

c. Eventualities can vary in the way that they are realised.

These properties can, in turn, be used to derive the linguistic eventuality tests listed below.

(3) Linguistic diagnostics for eventualities:

a. Eventuality expressions can serve as infinitival complements of perception verbs.

b. Eventuality expressions combine with locative and temporal modifiers.

c. Eventuality expressions combine with manner adverbials, instrumentals, comitatives, etc.

These assumptions about the Davidsonian notion of events are fairly standard; see Maienborn $(2003 \mathrm{a}, 2004)$ for a more detailed discussion. The diagnostics in (3) provide a way to detect hidden event arguments. In what follows, I use German sentences for illustration; see Maienborn (2003b) for a discussion of the Spanish copula forms ser and estar.

The behaviour of state verbs and statives with respect to perception reports is illustrated in (4). While state verbs can serve as infinitival complements of perception verbs (cf. (4a-c)), statives - including copula constructions - are prohibited in these contexts; cf. (4d-g).

(4) Perception reports:

a. Ich sah das Buch auf dem Tisch liegen.

I saw the book on the table lie.

b. Ich sah Bardo schlafen.

I saw Bardo sleep. 
c. Ich sah die Schuhe glänzen.

I saw the shoes gleam.

d. * Ich sah das Buch auf dem Tisch sein.

I saw the book on the table be.

e. * Ich hörte das Radio laut sein.

I heard the radio loud be.

f. * Ich sah die Tomaten $1 \mathrm{Kg}$ wiegen

I saw the tomatoes $1 \mathrm{~kg}$ weigh.

g. * Ich sah meine Tante Romy Schneider ähneln.

I saw my aunt Romy Schneider resemble.

In addition, as (5a-c) shows, state verbs combine with locative modifiers, whereas statives do not; see (5d-g). ${ }^{6}$

(5) Locative modifiers:

a. Das Auto wartet an der Ampel.

The car waits at the traffic light.

b. Bardo schläft in der Hängematte.

Bardo sleeps in the hammock.

c. Die Perlen glänzen in ihrem Haar

The pearls gleam in her hair

d. * Das Kleid ist auf der Wäscheleine nass.

The dress is on the clothesline wet.

e. * Bardo ist vor dem Kühlschrank hungrig

Bardo is in-front-of the fridge hungry.

f. * Die Tomaten wiegen neben den Paprikas $1 \mathrm{Kg}$.

The tomatoes weigh besides the paprikas $1 \mathrm{~kg}$.

g. * Bardo weiß (gerade) dort drüben die Antwort.

Bardo knows (at-this-moment) over there the answer.

The same pattern can also be observed with manner adverbials, comitatives and the

like - that is, modifiers that elaborate on the internal functional structure of eventualities. State verbs combine regularly with them, whereas statives do not, as (6) shows. (See also Katz $(2000,2003)$, where it is claimed that manner adverbs cannot occur with stative verbs. Some apparent counterexamples to this claim will be discussed in section 3.)

(6) Manner adverbials and similar expressions:

a. Bardo schläft friedlich/mit seinem Teddy/ohne Schnuller.

Bardo sleeps calmly /with his teddy /without dummy.

b. Carolin saß reglos /kerzengerade am Tisch.

Carolin sat motionless/straight as a die at.the table.

c. Die Perlen glänzen matt/rötlich /feucht.

The pearls gleam dully/reddishly/moistly. 
d. * Bardo war friedlich/mit seinem Teddy/ohne Schnuller müde. Bardo was calmly /with his teddy/ without dummy tired. e. * Carolin war unruhig /geduldig durstig.

Carolin was restlessly/patiently thirsty.

f. * Andrea ähnelt mit ihrer Tochter Romy Schneider.

Andrea resembles with her daughter Romy Schneider.

g. * Bardo besitzt sparsam/spendabel viel Geld.

Bardo owns thriftily/generously much money.

In sum, state verbs and statives differ sharply with respect to all of the standard eventuality diagnostics; see Maienborn (2003a, 2004) for further eventuality diagnostics yielding the same results. In view of the evidence given in (4)-(6), we can conclude that state verbs denote true Davidsonian eventualities, that is, Davidsonian states (or "D-states" for short). Statives, on the other hand, appear to resist a Davidsonian analysis.

\subsection{A Kimian approach to statives}

Maienborn (2003a, 2004) develops an alternative approach, according to which copular constructions (as exponents of the class of statives) refer instead to Kimian states (or "K-states" for short). Kimian states combine Kim's $(1969,1976)$ notion of temporally bound property exemplifications ${ }^{8}$ with Asher's $(1993,2000)$ conception of abstract objects as mentally constructed entities. ${ }^{9}$ Kimian states are tentatively characterised as follows:

(7) Kimian states

$\mathrm{K}$-states are abstract objects for the exemplification of a property $\mathrm{P}$ at a holder $\mathrm{x}$ and a time $\mathrm{t}$

From this definition, the properties given in (8) follow, with properties (8a) and ( $8 b$ ) due specifically to the status of $\mathrm{K}$-states as abstract objects.

(8) Ontological properties of Kimian states:

a. K-states are not accessible to direct perception and have no location in space.

b. K-states are accessible to (higher) cognitive operations.

c. K-states can be located in time.

(9) gives the corresponding linguistic diagnostics.

(9) Linguistic diagnostics for Kimian states:

a. K-state expressions cannot serve as infinitival complements of perception verbs and do not combine with locative modifiers.

b. K-state expressions are accessible for anaphoric reference

c. K-state expressions combine with temporal modifiers. 
The characterisation of Kimian states given in (7)-(9) parallels that of Davidsonian eventualities in (1)-(3) and accounts for the previously observed behaviour of statives with respect to the eventuality diagnostics (see (4)-(6)), as well as for their combination with temporal modifiers, as illustrated in (10).

(10) Temporal modifiers:

a. Carolin war gestern /immer/zweimal/tagelang müde. Carolin was yesterday/always/twice /for days tired.

b. Die 3 war gestern /immer/zweimal/jahrelang Bardos Glückszahl The 3 was yesterday/always/twice /for years Bardo's lucky number.

c. Bardo besa $ß$ jahrelang/in seiner Jugend ein Haus am See.

Bardo owned for years/in his youth a house at.the lake.

d. Carolin kannte immer/nie /wieder/letztes Jahr Leonardos Adresse. Carolin knew always/never/again /last year Leonardo's address.

The K-state approach also accounts for the observation that statives are subject to a particular kind of anaphoric reference, as shown in (11). In (11a), for example, the anaphoric pronoun das refers back to some "state" of Carolin being angry. Notice that das cannot be analysed as a fact anaphor here, given that facts are atemporal (e.g. Asher 1993, 2000).

(11) Anaphoric reference:

a. Carolin ist wütend. Das wird bald vorbei sein.

Carolin is angry. This will soon over be.

b. Der Schlüssel war weg und das seit dem Wochenende.

The key was away and this since the weekend.

c. Das Ol kostet $30 \$$. Das dauert nun schon 3 Monate.

The oil costs $30 \$$. This lasts already 3 months.

d. Carolin wog zu viel. Das endete erst mit der Pubertät.

Carolin weighed too much. This ended not-until with the puberty.

The evidence presented so far suggests that statives do indeed introduce an underlying argument that is, however, ontologically "poorer" than Davidsonian event arguments. The entity referred to by statives cannot be perceived, located in space, or vary in the way that it is realised, but it can be located in time and may serve as an antecedent for anaphoric reference. ${ }^{10}$ Kimian states were designed to account for this behavior. I will come back to the issue of anaphoric reference in section 4 .

(12) shows the lexical entry for English be, German sein, Spanish ser, etc. proposed in Maienborn (2003a, b, 2004).

(12) be/sein/ser..: $\lambda \mathrm{P} \lambda \mathrm{x} \lambda \mathrm{z}[\mathrm{z} \approx[\mathrm{P}(\mathrm{x})]]$

The copula introduces a referential argument $\mathrm{z}$ of type $\mathrm{K}$-state, which is characterised by the predicate $\mathrm{P}$ applying to the individual $\mathrm{x}$. The corresponding entry for a stative verb is given in (13) 
(13) ähneln 'resemble': $\lambda \mathrm{y} \lambda \mathrm{x} \lambda \mathrm{z}[\mathrm{z} \approx[\operatorname{resemble}(\mathrm{x}, \mathrm{y})]]$

(14) and (15) illustrate the compositional derivation of a copular construction and a stative expression, respectively.

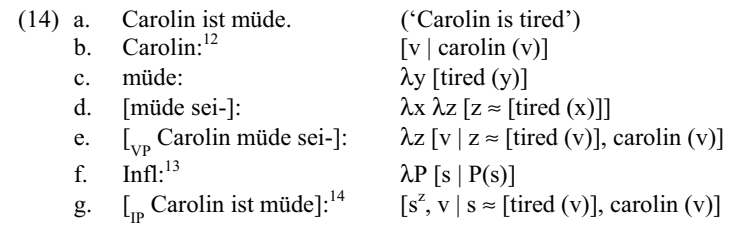

(15) a. Carolin ähnelt Bardo. ('Carolin resembles Bardo')

b. $\left[{ }_{\mathrm{V}}\right.$, Bardo ähnel-]: $\quad \lambda \mathrm{x} \lambda \mathrm{z}[\mathrm{u} \mid \mathrm{z} \approx[\operatorname{resemble}(\mathrm{x}, \mathrm{u})]$, bardo $(\mathrm{u})]$

c. $\left[_{\mathrm{VP}}\right.$ Carolin Bardo ähnel-]: $\lambda \mathrm{z}[\mathrm{v}, \mathrm{u} \mid \mathrm{z} \approx[\operatorname{resemble}(\mathrm{v}, \mathrm{u})]$, bardo $(\mathrm{u})$, carolin $(\mathrm{v})]$

d. $\quad{ }_{\text {IP }}$ Carolin ähnelt Bardo]: $\quad\left[\mathrm{s}^{\mathrm{z}}, \mathrm{v}, \mathrm{u} \mid \mathrm{s} \approx[\operatorname{resemble}(\mathrm{v}, \mathrm{u})]\right.$, bardo $(\mathrm{u})$, carolin (v)]

(16) provides the corresponding composition of a Davidsonian state verb for purposes of comparison. (For the sake of simplicity, I adopt the neo-Davidsonian convention of adding the participants of an eventuality by means of thematic roles (cf., e.g., Parsons 1990); but see Bierwisch (to appear) for critical remarks on this practice.)
(16) a. Carolin schläft
b. schlafen:
('Carolin is sleeping')
c. [ ${ }_{\mathrm{VP}}$ Carolin schlaf-]:
$\lambda \mathrm{x} \lambda \mathrm{e}$ [ sleep (e), theme $(\mathrm{e}, \mathrm{x})]$
d. $[$ IP Carolin schläft]:
$\lambda \mathrm{e}[\mathrm{v} \mid$ sleep $(\mathrm{e})$, theme $(\mathrm{e}, \mathrm{v})$, carolin $(\mathrm{v})]$
$\left[\mathrm{s}^{\mathrm{e}}, \mathrm{v} \mid\right.$ sleep $(\mathrm{s})$, theme $(\mathrm{s}, \mathrm{v})$, carolin (v)]

As (14)-(16) show, the difference between K-state and D-state expressions basically consists in a sortal contrast, which can be exploited in the course of building up the compositional meaning. That is, while eventuality arguments are suitable targets for locative modifiers, manner adverbials, and the like, K-state arguments won't tolerate them. The difference disappears as soon as the verb's referential argument is existentially bound by Infl. Therefore, the present account predicts that K-state and D-state expressions do not differ with respect to the admissibility of, e.g., "higher", sentential modifiers; see footnote 6 .

This ends our brief review of the theory of statives developed in Maienborn (2003a, 2004). 


\section{SOME APPARENT COUNTEREXAMPLES}

One kind of evidence for the claim that statives do not refer to Davidsonian states but to something ontologically "poorer" comes from their inability to combine with manner adverbials, as shown in (6) above. In contrast to Davidsonian eventualities, which display a rich spectrum of possible realisations, the referents of statives apparently cannot vary in the way that they are realised. Yet, as has been occasionally observed by proponents of the neo-Davidsonian approach, there seem to be at least some instances of manner modification with statives. This might indicate that we have been too hasty in dismissing the possibility that statives have a hidden eventuality argument and that these cases do call for such an argument after all

Let us take a closer look at the kind of evidence that has been offered for this analysis in the literature. A representative sample is given in (17)-(20). ${ }^{15}$

(17) John was a Catholic with great passion in his youth.

(Jäger 2001: 101)

(18) Peter war mit Begeisterung Angler. Peter was with enthusiasm angler.

(Dölling 2003: 529)

(19) Dan is in the country illegally.

(Mittwoch to appear)

(20) The board is coarsely grooved.

(Parsons 2000: 86)

In what follows, I will argue that these cases all involve some kind of non-compositional reinterpretation and therefore do not support a plain Davidsonian analysis for statives after all. ${ }^{16}$

The cases of (17) and (18) are rather straightforward. What John is passionate about in (17) is not the state of being a Catholic but the activities associated with this (Kimian) state (e.g. going to mass, praying, going to confession). The same holds true for (18), which requires us to infer activities related to the deverbal noun Angler 'angler'. If, however, no related activities come to mind for some predicate, such as being a relative (of Grit), as given in (21), then the sentence becomes odd.

(21) ??John was a relative (of Grit) with great passion.

This suggests that the combination of these manner adverbials (more specifically mental-attitude adverbials, according to the terminology of, e.g., Ernst 2002, 2003) with statives does not proceed regularly but relies on a reinterpretation process based on event coercion (e.g. Pustejovsky 1995; Egg 2001). That is, the sortal requirements of mental-attitude adverbials, which are not fulfilled by stative expressions, force us to infer a suitable event that stands in some natural relation to the given stative. Once this event has been (non-compositionally) inserted, it may serve as the target for the adverbial's meaning contribution. Obviously, such inferences rely heavily on world knowledge, and their plausibility depends on the presence of (or the hearer's ability to supply) a suitable context. If statives had a Davidsonian 
eventuality argument right from the start, no such additional inferential processes would be necessary, and unacceptable cases like (21) would not be expected.

In Maienborn (2003a), I sketch a formal treatment of this kind of event coercion (based on van der Sandt's (1992) account of presuppositions). The basic idea is that such event coercion takes as presuppositions the sortal requirements of a modifier that conflict with the modifier's compositionally designated target and, if possible, accommodates these requirments by introducing a new event referent into the universe of discourse.

Notice that this approach allows us to preserve the well-established Davidsonian analysis of adverbial modification as conjunction of event predicates and thus to account for the characteristic Davidsonian inference patterns of modifier drop (Parsons 2000), which Jäger (2001: 101) also observes for stative sentences like (17).

(17') a. John was a Catholic with great passion in his youth.

b. John was a Catholic in his youth.

c. John was a Catholic with great passion.

d. John was a Catholic.

I agree with Jäger that, for example, sentence (17'a) entails (17'b-d), and both (17'b) and $(17$ 'c) entail (17'd). But I do not agree with his conclusion about these and similar data, as given below.

So if we consider the arguments for a Davidsonian treatment [of adverbial modification;

CM] compelling, we are forced to assume that statives have a Davidsonian argument,
too.
Jäger (2001: 102)

The validity of the inference pattern in (17') does indicate that the manner adverbial with great passion adds a simple event predicate that can be omitted salva veritate, given the logical rule of conjunction reduction. Yet, there is no reason to assume that the target of the manner adverbial is necessarily the regular referential argument of the stative. Rather, I would claim, the modifier's target event originates only in the course of reinterpreting the stative - a process which is triggered exactly by the stative's lack of an underlying eventuality argument. In short, the Davidsonian approach does not require us to account for inference patterns like (17') by surfaceoriented analyses.

The sentences in (22) give further illustrations of manner adverbials in the broad sense (including other obviously event-related modifiers like instrumentals and comitatives) that trigger event coercion when combined with statives.

(22) a. Hans ist mit den Hunden im Park. Hans is with the dogs in.the park.

b. Maria war schnell in der Stadt. Maria was quickly in the town.

c. Chirac war mit der Concorde in New York. Chirac was with the Concorde in New York. 
A sentence like (22a) can easily be (re)interpreted. The reason is that we are immediately able to associate characteristic activities with 'being in a park': jogging, relaxing, walking the dog, feeding ducks, etc. According to the argumentation developed above, this should not lead us to believe that (22a) is a regular, wellformed sentence, though. In fact, a structurally identical sentence like (22'a) sounds rather weird - unless we can infer a plausible scenario for 'being beside a window' that allows us to accommodate the required event argument.

(22') a. ?? Hans ist mit den Hunden neben dem Fenster Hans is with the dogs beside the window.

Analogously, the adverb schnell 'quickly' in (22b) does not modify the state of Maria's being in the city but an inferred event of her going to the city. Interestingly, the antonym langsam 'slowly' in (22'b) does not support such an ingressive coercion by which the sentence could be "rescued"; see Maienborn (2003a: 93-94) for a possible explanation.

(22') b.?? Maria war langsam in der Stadt. Maria was slowly in the town.

An ingressive coercion is also triggered by the instrumental mit der Concorde 'with the Concorde' in (22c) — and is blocked, once again, in (22'c).

(22') c. ?? Der Koffer war mit der Concorde in New York

The suitcase was with the Concorde in New York.

Note that a sentence like (22"c) is not compatible with a scenario in which Maria came to Italy by plane and then travelled around using a hired car. This underlines the need for a non-regular, ingressive coercion in order to integrate the instrumental adverbial.

(22”) c. Maria war mit einem Leihwagen in Italien. Maria was with a hired car in Italy.

We may now have a look at Mittwoch's example (19), which is repeated here:

(23) Dan is in the country illegally.

(Mittwoch to appear)

This seems like just the kind of counterevidence we are looking for: namely, true manner modification of a stative. Under this assumption, sentence (23) indicates that there is a (Davidsonian) state of the subject referent's being located in the country and this state is furthermore qualified as illegal. This is shown in the logical representation given in (24) 
(24) $\exists \mathrm{e}[$ be_located_in_the_country $(\mathrm{e}) \wedge$ theme $(\mathrm{e}$, dan $) \wedge$ illegal $(\mathrm{e})]$

On the basis of these and similar data, Mittwoch reaches the following conclusion:

Hence the empirical basis for a Davidsonian argument for states [statives in my terminology; CM] is thinner than in the case of events; the DA [Davidsonian argument; $\mathrm{CM}]$ has less work to do. But there is no difference in principle.

Mittwoch (to appear: 18)

I remain sceptical. In fact, closer inspection reveals that sentence (23) isn't as "innocent" as it first appears. ${ }^{17}$ First, if the compositionally determined meaning representation of the copular sentence (23) were really something like (24), why would the parallel sentence (25) not have a representation like (26), rather than being ungrammatical? (Remember that the crucial assumption of the neoDavidsonian approach is that every VP has a hidden eventuality argument. That is, trying to explain the ungrammaticality of (25) on neo-Davidsonian premises by assigning copula plus DP combinations an exceptional, i.e., non-Davidsonian, status (a) would be completely ad hoc and (b) wouldn't even work given (more or less) "well-behaved" copula plus DP combinations like (17) and (18).)

(25) * Dan is a UK resident illegally.

(26) $\exists e[$ be_a_UK_resident $(e) \wedge$ theme $(e$, dan $) \wedge$ illegal $(e)]$

Second, there are reasons to believe that the logical representation in (24) does not accurately reflect the meaning of sentence (23). Note that the structurally identical $\left(23^{\prime}\right)$ is odd, although it makes perfect sense. That is, the marginal acceptability of (23') apparently has no deep conceptual source but instead originates in the grammatical system.

(23') ? The car is on the factory premises illegally.

The German counterparts for (23)/(23') are given in (27)

(27) a. Dan ist illegal im Land.

Dan is illegally in.the country.

b. ? Das Auto ist illegal auf dem Fabrikgelände.

The car is illegally on the factory premises.

As we might expect, occurrence of illegally with a Davidsonian state verb is fine. (German intransitive parken 'park' refers to Davidsonian states; see also The car was parked on the factory premises illegally (for hours).)

(28) a. Das Auto parkt illegal auf dem Fabrikgelände.

The car parks illegally on the factory premises. 
b. Das Auto steht illegal auf dem Fabrikgelände.

The car stands illegally on the factory premises.

What all of this suggests is that, despite first appearances, the sentence in (23) (and, by the same token, (23') and (27)) does not display a regular combination of a stative and a manner adverbial after all. Rather, I would claim, (23) is just another instance of rescuing the combination of a manner adverbial with a stative via event coercion. That is, sentence (23) does not indicate merely that the state of the subject referent's being located in the country is illegal; what is actually illegal is the eventuality of residing there or staying there temporarily, which is inferred on the basis of the relevant Kimian state.

Why then, one might ask, is there no analogous "rescue operation" for (23')? In particular, in view of (28) it would be straightforward to reinterpret (23') by inferring a Davidsonian state of, for example, the car standing on the factory premises. Yet the conditions under which non-compositional event coercion may take place are apparently more restrictive. In Maienborn (2003a), this behaviour is accounted for in terms of optimality-theoretic pragmatics (Blutner 1998, 2000). Roughly speaking, rescuing ungrammatical combinations of statives with eventbased modifiers via event coercion will be tolerated only if there is no equally economical way of expressing the same meaning by means of a grammatically wellformed sentence. The violation of grammatical rules must be profitable, so to speak - hence the preference for inferring more or less complex activities; see Maienborn (2003a: chap. 6.2) for details

So far, all of the counterexamples to the claim being defended here have turned out to have an independent explanation, allowing us to preserve our claim. The only remaining evidence of manner modification with statives is the sentence in (20), which I repeat here for convenience.

(29) The board is coarsely grooved.

(Parsons 2000: 86)

In fact, (29) seems to be part of a rather productive pattern, further examples of which are given in (30). (See also Parsons (1990: 191-192). $)^{18}$

(30) a. Das Brett ist grob gefurcht. The board is coarsely grooved.

b. Das Fenster ist weit offen.

The window is wide(ly) open.

c. Die Tür ist fest zu.

The door is tightly shut

d. Die Tür war locker mit einem Lederriemen verschlossen.

The door was loosely with a leather belt closed.

e. Die Blumenbeete waren üppig bepflanzt.

The flower beds were lavishly planted.

f. Die Jacke ist dick gefüttert.

The coat is thickly lined. 
Parsons (1990: 191-192) takes data like these as strong support for an underlying event analysis of statives. ${ }^{19}$ According to this view, coarsely, wide, loosely, tightly, lavishly etc. predicate over Davidsonian states; see also Jäger (2001: 102). That is, the logical representation for, e.g., sentence (30b) would be something like (31).

(31) $\exists$ e $\left[\right.$ be_open $(e) \wedge$ theme $\left(e\right.$, the $\left.\_w i n d o w\right) \wedge$ wide $\left.(e)\right]$

In his study of manner adverbs, Geuder (2000) argues against such an analysis. He calls adverbs of the kind given in (29) and (30) "resultative adverbs", which he analyses as predicates not over states but over resultant objects, i.e., implicit objects resulting from an event. That is, sentence (30b) does not indicate that there is a state of the window being open and that this state is wide. What is, instead, qualified by the adverb is the gap between the window and its frame, which results from an opening event. Accordingly, the other modifiers should be analysed as predicates over grooves in (30a), a lock in $(30 \mathrm{c} / \mathrm{d})$, an ensemble of plants in $(30 \mathrm{e})$, and the lining of the coat in (30f).

Geuder's (2000) analysis fits neatly into the arguments presented here. The relevant modifiers do not apply to an alleged (Davidsonian) state argument introduced by a stative but have more specific sortal requirements, which statives do not fulfil. Therefore, the sentences are strictly speaking ungrammatical. Under special circumstances, however, a hearer can resolve the sortal conflict by inferring an appropriate event that yields a resultant object, which provides a suitable target for the modifier. That is, rather than (31), the final logical representation for (30b) should comprise at least the following information:

(32) $\exists z\left[z \approx[\right.$ open (the_window) $] \wedge \exists e, x$ [opening $(e) \wedge$ theme (e, the $\_$window) $\wedge$ resultant-state $(\bar{e})=\mathrm{z} \wedge$ resultant-object $(\mathrm{e})=\mathrm{x} \wedge$ gap $(\mathrm{x}) \wedge$ wide $(\mathrm{x})]]]$

Nothing but the first conjunct belongs to the regular compositional meaning of a copular construction. Everything else must be inferred in order for the modifier's contribution to be integrated into the logical representation.

Additional support for the kind of analysis advocated here comes from data like (33), which underline the need for a mediating event.

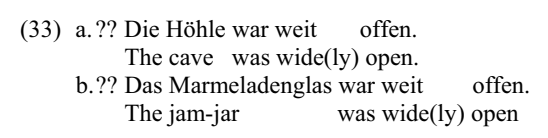

Although caves are natural openings, the adverbial modifier weit in (33a) cannot, it seems, apply directly to this referent, but requires the presence of a causing event. That is, in order to make (33a) acceptable, we have to assume a scenario in which the entrance of the cave was previously closed by, for example, a wooden wall which then was opened, thereby creating a new, artificial opening. 
Sentence (33b) indicates that it does not suffice to have an object like a jam jar, which can be opened and closed and has an opening, too. The problem here is that the jar's opening exists independently of an opening event and therefore does not qualify as the event's resultant object.

All of this shows that the (re)interpretation of sentences like (29), (30) and (33) (a) is dependent on world knowledge and more or less complex assumptions about the contextual setting, and (b) always involves some kind of event coercion.

In the case of adjectival passives, given the deverbal origin of the predicative AP, the respective event comes for free. This is why adjectival passives lend themselves to this construction.

Summing up the discussion so far, we have seen that apparent counterexamples to the claim that statives do not combine with manner adverbials turn out to involve event coercion. That is, special (extragrammatical) measures are to be taken in order to integrate the meaning contribution of these modifiers. The respective adverbials definitely do not directly modify the referential argument introduced by statives. Hence, they do not support but rather refute a Davidsonian analysis of statives.

\section{CONSIDERATIONS FROM TIME TRAVEL}

Does Parsons' recently presented time travel argument fare better in providing support for a Davidsonian approach to statives? Parsons (2000: 88) illustrates his argument with the following story situated in the ancient Greece:

Let us assume that Socrates is sitting outside the city walls and talking to Parmenides at a particular time. Some time later, Socrates stumbles into a time warp and travels back in time. After he emerges from the time warp (as the very same Socrates), he ponders his discussion with Parmenides for a while. Then - at the very same time that his discussion with Parmenides is taking place outside the city walls - Socrates lies down in the marketplace, where he begins cursing the gods.

With this little story, Parsons invites us to assume, for the sake of the argument, that the two sentences in (34) and (35) are both true at the same time. ${ }^{20}$

(34) Socrates is sitting outside the city walls and talking with Parmenides.

(35) Socrates is lying in the marketplace and cursing the gods

Now, here is the time travel argument. Consider the following inference pattern:
(36) a. Socrates is sitting.
(by conjunction reduction from (34))
b. Socrates is in the market place.
(by conj. reduction from (35))
c. $\therefore$ Socrates is sitting in the marketplace.
(by conjunction of $(36 \mathrm{a} / \mathrm{b}))$

Given that the conclusion in (36c) is obviously false, we have to make sure that this inference is blocked somehow by our logical analysis of (34) and (35). If we analysed the positional and locative predicates in (34) and (35) as predicates that 
apply to the individual Socrates, we would have no means to block the invalid inference in (36c). If, instead, we adopt a Davidsonian analysis, according to which the respective predicates apply to hidden state arguments as in (37), the invalid inference is, correctly, blocked. ((37) gives Parsons' (2000: 90) formulation.)

(37) a. For some state $s: s$ is a state of sitting $\wedge s$ is a state of being outside the city walls $\wedge$ Socrates is in $s$.

b. For some state $s: s$ is a state of lying $\wedge s$ is a state of being in the marketplace $\wedge$ Socrates is in $s$.

c. $\therefore$ For some state $s: s$ is a state of sitting $\wedge s$ is a state of being in the marketplace $\wedge$ Socrates is in $s$.

(invalid)

According to $(37 \mathrm{a} / \mathrm{b})$, Socrates is simultaneously in two different states. There is no state that has both the property of being a sitting state and that of being located in the marketplace. Therefore there is no way to derive the inference in $(37 \mathrm{c})$. This is, in short, the time travel argument. Parsons concludes:

Considerations of how we describe what takes place in time travel stories suggest that there are underlying states in stative sentences involving state verbs and copulative sentences with adjectives, locatives, and nouns. Parsons (2000: 92)

As this quotation shows, Parsons does not distinguish between the two kinds of states differentiated here but takes both copular constructions and state verbs like sit and lie to belong to one and the same class of state expressions. So let us evaluate Parsons' time travel argument in terms of the analysis advocated here.

As it stands, Parsons' argument provides a further piece of evidence in favour of a Davidsonian approach to state verbs. Moreover, it is consistent with the behaviour of state verbs with respect to standard eventuality tests, as reported in section 2.1. Yet, as our considerations in section 2.1 have also shown, this behaviour by no means carries over to statives.

What would a stative version of Parsons' time travel argument look like? Let us try (38). Of course, we shouldn't be able to infer (38c) from (38a) and (38b). But, this will never happen, simply because the sentences in $(38 \mathrm{a} / \mathrm{b})$ are grammatically ill-formed. Our previous considerations have shown that statives do not tolerate any kind of modifier that could fit into this pattern.

(38) a. Socrates is \{in an $\mathrm{X}$-way, with Parmenides, at location $\mathrm{X}$ \} hungry. b. Socrates is \{in a Y-way, without Parmenides, at location Y $\}$ full. c. $\therefore$ Socrates is $\{$ in an $\mathrm{X}$-way, with Parmenides, at location $\mathrm{X}\}$ full.

That is, according to the analysis of statives defended here, the invalid inference does not emerge because there are no legitimate premises in the first place. Thus, Parsons' time travel argument does not carry over to statives. Once again, we haven't found the slightest hint of a hidden Davidsonian eventuality argument.

However, in what follows, I will show that Parsons' argument, suitably adapted, may indeed provide additional support for the Kimian alternative advocated here. 
The data that my version of the time travel argument will build on is related to the German anaphoric expression dabei (literally: 'thereat').

As illustrated in (39), dabei adds some accompanying circumstance to its antecedent. Sentence (39b), for example, indicates that the Davidsonian state of Carolin waiting for the bus is accompanied by her reading a book.

(39) a. Bardo tanzte und klatschte dabei mit den Händen. Bardo danced and clapped thereat with the hands.

b. Carolin wartete auf den Bus und las dabei ein Buch. Carolin waited for the bus and read thereat a book.

As the sentences in (40) show, dabei is not reserved for Davidsonian eventualities but may also be used for Kimian states.

(40) a. Es war kalt und dabei regnerisch. It was cold and thereat rainy.

b. Bardo war krank und lief dabei ohne Schal herum

Bardo was ill and walked thereat without scarf about.

c. Die Zwei ist eine Primzahl und dabei gerade.

The two is a prime number and thereat even.

Sentence (40b), for example, is thus interpreted as indicating that the Kimian state of Bardo being ill is accompanied by (possibly iterated) events of Bardo walking about without a scarf. (Notice that the antecedent of dabei may also be introduced by a copular individual-level predicate like 'being a prime number', as in (40c).)

In section 2.2, Kimian states were characterised as entities that are ontologically "poorer" than Davidsonian eventualities. In fact, up to now we have seen only the temporal dimension of Kimian states; see (10). This raises the question whether we need such an ontological category at all. Wouldn't it suffice to assume that statives just introduce a temporal argument? This temporal argument could then serve as a target for temporal modification. Following this line of reasoning, we could then say that the anaphoric expression dabei in (40) refers back to the time interval at which the respective property holds and expresses temporal overlap.

At this point, Parsons' time travel argument can be used to show that dabei does not express mere overlap between two time intervals but relates to the "substance" of its antecedent. That is, dabei really calls for a reification of the denotatum of statives, consistent with the assumption of Kimian states.

So let us once again tell a little time travel story about Socrates. This time, Socrates is outside the city walls, weak from hunger, when he stumbles into the time warp and is in the marketplace and full afterwards. In other words, let us take sentences (41a) and (41b) both to be true at the same time with the same Socrates. While (41c) is a valid inference from $(41 \mathrm{a} / \mathrm{b})$, the conclusion in (41d) is invalid and should therefore be blocked. 
(41) a. Sokrates ist außerhalb der Stadtmauern und er ist dabei hungrig. Socrates is outside the city walls and he is thereat hungry.

b. Sokrates ist auf dem Marktplatz und er ist dabei satt.

Socrates is in the marketplace and he is thereat full.

c. $\therefore$ Sokrates ist auf dem Marktplatz und er ist gleichzeitig hungrig. Socrates is in the marketplace and he is at the same time hungry.

d. $\therefore$ Sokrates ist auf dem Marktplatz und er ist dabei hungrig. Socrates is in the marketplace and he is thereat hungry. (invalid)

This indicates that dabei does not refer back to a mere time interval but calls for a reification of the denotatum of its antecedent. That is, the antecedent of dabei in (41a), for example, must be some temporal entity qualified by the property of Socrates being located outside the city walls. This is precisely what Kimian states allow us to capture.

\section{CONCLUSION}

In a recent overview of the role that events play in linguistic semantics, Higginbotham (2000) reaches the following conclusion about the presence of Davidsonian eventuality arguments in natural language expressions:

The arguments in favour of the hypothesis point toward a restricted theory of linguistic complation as they are linguistically organisation: events enter semantic computation only as they are linguistically
represented through thematic grids, and discharge of open positions takes place only represented through thematic grids, and discharge of open positions takes place only under structurally controlled conditions. The theory pays for in ontology what it buys
semantically - that is, the cost, if it is a cost, of the combinatorial simplification is the positing of objects, reference to which is not immediately manifest in linguistic positing of objects, reference to which is not immediately manifest in linguistic
structures.
Higginbotham (2000: 76)

What I have done in this paper is to weigh the grammatical/ontological costs and benefits of postulating hidden Davidsonian arguments for statives The results are, I think, quite clear: the grammatical benefit tends toward zero, while the grammatical and ontological costs are quite high.

As regards the purported benefits of this hidden Davidsonian argument, if statives did have such arguments, they must, keep them very well hidden, since - in the course of a compositional semantic derivation, at least - they never show up.

As for the costs, if statives were equipped with Davidsonian eventuality arguments, there would have to be some grammatical (and perhaps supplementary pragmatic) explanation for why their behaviour is so radically different from that of other eventuality expressions. Moreover, a radical redefinition of the category of eventualities would also seem to be required, given that the central assumption that eventualities are spatiotemporal entities (with functionally integrated participants) could no longer be maintained; see Maienborn (2004).

By way of conclusion, I would like to compare the Kimian approach to statives advocated here with two alternatives in the literature.

One approach is represented by the work of authors like Bäuerle (1994), Katz $(2000,2003)$ and Jäger (2001), who take the borderline drawn by the eventuality 
diagnostics in section 2.1 to coincide with an opposition between events and states. While Bäuerle (1994) and Jäger (2001) take the crucial difference to be location in space - they claim that events (including processes) but not states can be located in space - Katz $(2000,2003)$ accounts for the event/state opposition in terms of the presence or absence of a Davidsonian eventuality argument. There appears to be no place for Davidsonian state verbs in this picture. However, the fact that they fully satisfy the criteria for Davidsonian eventuality expressions argues against any marginalisation of verbs like sit, stand, lie, sleep, and wait.

What the linguistic evidence leads us to conclude, then, is that a class of static eventualities (= Davidsonian states) does exist; and that the event/state opposition cannot help us clarify the difference between eventuality expressions and statives.

A second approach is represented by the work of Dölling (1999), who tries to account for the peculiar behaviour of statives within a neo-Davidsonian framework by distinguishing two subtypes of states. According to Dölling, sit, stand, sleep, wait, etc. belong to the subtype of states that can be located in space, whereas statives build a subtype that has no location in space. That is, Dölling wants to subsume both Davidsonian and Kimian states under the ontological category of eventualities. ${ }^{21}$ On this view, Kimian states would be just a special sort of eventualities - eventualities, that, according to our findings in section 2.1 , can be neither perceived nor located in space and cannot vary in the way that they are realised.

In my view, such a move creates two major problems. First, what would be the smallest common denominator for events, processes, and Davidsonian states, on the one hand, and Kimian states, on the other? If we were to adopt such a liberal perspective, the only thing we could say about eventualities would be that they have a temporal dimension and some further content. That is, Kimian states would set the tone for the whole category of eventualities. This is clearly inadequate. Second, postulating two kinds of states as subtypes of the category of eventualities, depending on whether they can be located in space or not, is completely ad hoc. Remember that the subdivision of eventualities into events, processes, and states was based on temporal/aspectual criteria in the tradition of Vendler (1967). Why should nondynamic, homogeneous eventualities (i.e. states) divide into spatial and non-spatial subtypes? And why should the non-spatial instances moreover exclude manner variance? This does not follow from their ontological properties, and would have to be stipulated.

In sum, trying to adapt the ontological category of Davidsonian eventualities in such a way that Kimian states can be subsumed under them inevitably requires us to renounce all of the benefits of the Davidsonian approach. It seems worthwhile, then, to continue to explore the idea of supplementing the ontological category of Davidsonian eventualities with Kimian states, in order to account adequately for both eventive and stative expressions.

Humboldt University Berlin

Department of German Language and Linguistics

Unter den Linden 6

10099 Berlin, Germany 
NOTES

I am greatful to the volume editors and two anonymous reviewers, who gave me very valuable comments. Thanks also to Benjamin Shaer and Susan Olsen for checking my English.

Throughout this paper, I will use the term "event" as a synonym for Bach's (1986) notion "eventuality", i.e., as a cover term for events proper (accomplishments and achievements in Vendler's (1967) terms), processes (Vendler's activities) and certain (viz. Davidsonian; see below) states.

Other relevant studies include Dölling $(1999,2003)$ and, recently, Mittwoch (to appear). See also Montmarquet (1980: 251), who notes that "all of Davidson's arguments for events serve equally well to provide proper ontological credentials for states", and that "states are like Davidsonian events in being unrepeatable particulars; they differ only in not being changes."

3 Parsons (2000: 88): "Based on the considerations reviewed above, it would appear that the underlying state analysis is not compelling for any kind of the constructions reviewed here and is not even plausible for some (e.g., for nouns). There are a few outstanding problems that the underlying state analysis might solve, $[\ldots]$ but for the most part the weight of evidence seems to go the other way. In the next section we look at some new evidence."

Verbs like sleep and wait are sometimes analysed as expressing dynamic eventualities, i.e., processes. Following, e.g., Dowty (1979) and Krifka (1989), I assume that the crucial difference between (conceptualisations of) processes and states is related to their subinterval properties: while processes have a lower bound on the size of subintervals that are of the same type (e.g., breath, run, glitter) states have no such lower bound - i.e., they also hold at atomic times. By this criterion sleep, wait, gleam etc. (likewise sit, stand, hang etc.) clearly belong to the category of state expressions. See Maienborn (2003a, 2004) for a collection of linguistic diagnostics that help distinguish state from process expressions.

The stage-level/individual-level distinction goes back to Carlson (1977) (building on earlier work by Milsark 1974, 1977) and has been given an event semantic treatment by Kratzer (1995). On this treatment, stage-level predicates are assumed to have an additional event argument, while individuallevel predicates lack such an argument. See Maienborn (2003a) for an overview of further developments based on Kratzer's approach.

Note that when using locatives as eventuality diagnostics we have to make sure that we are checking for locative VP-modifiers. These should not be confused with frame-setting locatives such as (i)-(iii). The latter, being sentential modifiers, do not relate to an underlying eventuality argument, but instead (2001) for more details about the syntax and semantics of frame-setting locatives.

(i) Bei Kerzenlicht ähnelt Carolin ihrem Bruder. In candle light resembles Carolin her brother.

(ii) In der Wiener Staatsoper heißt der Souffleur "Maestro Suggeritore". In the Vienna state opera is-called the prompter "Maestro Suggeritore".

(iii) Im Kindergarten war Bardo brav.

In.the kindergarten was Bardo well-behaved.

${ }^{7}$ In Maienborn (2003b) these eventuality diagnostics are applied to the Spanish copula forms ser and estar (which are generally considered to be lexical exponents of the stage-level/individual-level distinction). The results reported in that study confirm this conclusion: neither ser nor estar meets any of the eventuality criteria. The Spanish copula forms do not differ from their German or English ser/estar, as proposed within the stage-level/individual-level paradigm. Maienborn (2003b) develops a discourse-based account of ser/estar instead.

8 While Kim understood his proposal as an alternative to Davidson's approach, I think of K-states as a supplement to Davidsonian eventualities.

According to Asher $(1993,2000)$, abstract objects (like facts and propositions) are introduced for efficient natural language processing and other cognitive operations but do not exist independently of

them. Roughly speaking, abstract objects exist only because we talk and think about them.
${ }^{10}$ It might be worth pointing out that our characterisation of K-states as having no location in space (see (8a)) does not exclude copular constructions with locative main predicates, as illustrated in (i). Like 
any other copular construction, (i) assigns a property (here: the property of being located in the garden) to the subject referent. That is, locative copular constructions do not locate some underlying state argument, but the object (or eventuality) referred to by the subject referent.

(i) Carolin ist im Garten

Carolin ist im Garten.
Carolin is in.the garden.

${ }^{11}$ The following representations use the formal framework of Discourse Representation Theory (DRT; Kamp 1981; Kamp and Reyle 1993). See Asher (1993) for the compositional DRT variant with $\lambda$ abstraction employed here. I use a flat notation for DRSs: discourse referents are separated from DRS conditions by a straight line; see the notational convention in (i).

(i) Notation: $\lambda \mathrm{y} \lambda \mathrm{x} \ldots$ [discourse referents $\mid$ DRS conditions]

Variables are sorted as follows. $x, y, u, v$ : individuals; $z$ : K-states; e: eventualities; s: K-states $U$ eventualities; P, Q, R: first-order predicate.

Asher (1993: 145f) defines " $\approx$ " as relating a discourse referent for an abstract object (facts, propositions etc.) to a DRS that characterises this discourse referent; cf. Maienborn (2003a, 2004) for details.

${ }^{12}$ For the sake of simplicity, I will assume that a proper name introduces a discourse referent $\mathrm{v}$ into the

universe of discourse, as in (14b).
${ }^{13}$ Note that Infl as defined in (14f) introduces a discourse referent $\mathrm{s}$ for the referential argument of the VP. This corresponds to the operation of existential closure in alternative frameworks. That is, in the notation of predicate logic, the DRS for Infl in (14f) would correspond to (i).

(i) Infl: $\lambda \mathrm{P} \exists \mathrm{s}[\mathrm{P}(\mathrm{s})]$.

${ }^{14}$ Note that in the course of applying Infl (14f) to an K-state VP like (14e), Infl's discourse referent s which originally ranges over eventualities and K-states is narrowed down to the domain of K-states. This is indicated in $(14 \mathrm{~g})$ by the addition of a superscript $\mathrm{z}$ to $\mathrm{s}$ within the universe of discourse.

In the following, I will concentrate on the combination of manner adverbials with copular constructions. Cases of (apparent) manner modification with stative verbs like know personally, love passionately, and believe firmly are discussed in Katz $(2000,2003)$.

As one reviewer remarks, Jäger's sentence (17) is judged as rather bad English by native speakers. This fits well with the view defended here, according to which a sentence like (17) might be interpretable somehow by some mechanism of meaning coercion (see below), but it nevertheless remains ungramitical becul

${ }^{17}$ Thanks to Anita Mittwoch for bringing this example to my attention and for discussing it with me. Thanks also to Thomas Ernst and Benjamin Shaer for discussion and judgements.

${ }^{18}$ Note that the participial forms in (30) are unambiguously socalled "adjectival passives" (i.e. combinations of the copula be plus a deverbal adjective), since "verbal" (i.e. true) passives take the auxiliary werden in German; see, e.g., Kratzer $(1994,2000)$.

19 Parsons (2000) is a bit more sceptical. With respect to sentence (29) he notes: "The problem about these constructions is that they seem to occur only when the adjective is spelled like the past participle of a verb: grooved is an example. The construction is thus quite restricted and special and cries out for of a verb: grooved is an example. The construction is thus quite restricted and special and cries out for
some special explanation" (Parsons 2000: 86). For this reason, I will concentrate on (30b) The window is wide open in the discussion in the text. My claim will be that not only adjectival passives but also true adjectives cry for a special, non-compositional explanation.

${ }^{20}$ Parsons admits that the assumption of time travel raises intricate philosophical problems. But, he goes on, "contemplation of cases of time travel can force us to clarify our theories about ordinary situations" (Parsons 2000: 88)

${ }^{21}$ The proposals of Dowty (1979) and Bach (1986) point in the same direction. According to Dowty (1979: 180ff), sit, stand, lie, etc. belong to the subtype of "interval statives" (see the table in Dowty 1979: 184). Bach (1986: 6) distinguishes "dynamic states" described by, e.g., sit, stand, and lie from "static states" described by statives. 


\section{REFERENCES}

Asher, N. (1993). Reference to Abstract Objects in Discourse. Dordrecht: Kluwer

Asher, N. (2000). Events, Facts, Propositions, and Evolutive Anaphora. In J. Higginbotham, F. Pianesi \& A. Varzi (Eds.), Speaking of Events (pp. 123-150). New York, Oxford: Oxford University Press.

Bach, E. (1986). The algebra of events. Linguistics and Philosophy, 9, 5-16.

Bäuerle, R. (1994). Zustand - Prozess - Ereignis. Zur Kategorisierung von Verb(al)phrasen. Wuppertaler Arbeitspapiere zur Sprachwissenschaft, 10,1-32.

Bierwisch, M. (to appear). The Event Structure of CAUSE and BECOME. In C. Maienborn \& A. Wöllstein (Eds.), Event Arguments in Syntax, Semantics, and Discourse. Tübingen: Niemeyer.

(Eds.), Event Arguments in Syntax, Semantics, and Discourse. Tübingen:
Blutner, R. (1998). Lexical Pragmatics. Journal of Semantics, 15(2), 115-162.

Blutner, R. (2000). Some Aspects of Optimality in Natural Language Interpretation. Journal of Semantics, $17,189-216$.

Chierchin, G. (1995). Individual-Level Predicates as Inherent Generics. In G. N. Carlson \& F. J. Pelletier (Eds.), The Generic Book (pp. 176-223). Chicago, London: The University of Chicago Press.

(Eds.), The Generic Book (pp. 176-223). Chicago, London: The University of Chicago Press.
Davidson, D. (1967). The Logical Form of Action Sentences. In N. Resher (Ed.), The Logic of Decision and Action (pp. 81-95). Pittsburgh: University of Pittsbur.

Diesing, M. (1992). Bare Plural Subjects and the Derivation of Logical Representations. Linguistic Inquiry, 23(3), 353-380.

Dölling, J. (1999). Kopulasätze als Zustandsbeschreibungen. ZAS Papers in Linguistics, 14, 95-122.

Dölling, J. (2003). Flexibility in adverbal modification: Reinterpretation as contextual enrichment. In E. Lang, C. Maienborn \& C. Fabricius-Hansen (Eds.), Modifying Adjuncts (pp. 511-552). Berlin: Mouton de Gruyter.

Dowty, D. R. (1979). Word Meaning and Montague Grammar. Dordrecht: Reidel.

Egg, M. (2001). Beginning novels and finishing hamburgers - Remarks on the semantics of to begin. Linguistische Arbeitsberichte, 76, 295-319.

Ernst, T. (2002). The Syntax of Adjuncts. Cambridge: Cambridge University Press.

Ernst, T. (2003). Semantic features and the distribution of adverbs. In E. Lang. C. Maienborn \& C. Fabricius-Hansen (Eds.), Modifying Adjuncts (pp. 307-334). Berlin: Mouton de Gruyter.

Geuder, W. (2000). Oriented Adverbs. Issues in the Lexical Semantics of Event Adverbs. Unpublished Diss., University of Tübingen.

Higginbotham, J. (1985). On Semantics. Linguistic Inquiry, 16, 547-593.

Higginbotham, J. (2000). On Events in Linguistic Semantics. In J. Higginbotham, F. Pianesi \& A. Varzi (Eds.), Speaking of Events (pp. 49-79). New York, Oxford: Oxford University Press

Jäger, G. (2001). Topic-Comment Structure and the Contrast between Stage Level and Individual Level Predicates. Journal of Semantics, 18, 83-126.

Kamp, H. (1981). A Theory of Truth and Semantic Representation. In J. Groenendijk, T. Janssen \& M. Stokhof (Eds.), Formal Methods in the Study of Language (pp. 277-322). Amsterdam: Mathematisch Centrum.

Kamp, H., \& Reyle, U. (1993). From Discourse to Logic. Introduction to Modeltheoretic Semantics of Natural Language, Formal Logic and Discourse Representation Theory. Dordrecht: Kluwer.

Katz, G. (2000). Anti Neo-Davidsonianism: Against a Davidsonian Semantics for State Sentences. In C Tenny \& J. Pustejovsky (Eds.), Events as Grammatical Objects (pp. 393-416). Stanford, CA: CSLI Publications.

Katz, G. (2003). Event arguments, adverb selection, and the Stative Adverb Gap. In E. Lang, C. Maienborn \& C. Fabricius-Hansen (Eds.), Modifying Adjuncts (pp. 455-474). Berlin: Mouton de Gruyter.

Kim, J. (1969). Events and their Descriptions: Some Considerations. In N. R. e. al (Ed.), Essays in Honor of Carl G. Hempel (pp. 198-215). Dordrecht: Reidel.

Kim, J. (1976). Events as Property Exemplifications. In M. Brand \& D. Walton (Eds.), Action Theory. Proceedings of the Winnipeg Conference on Human Action (pp. 159-177). Dordrecht: Reidel.

Kratzer, A. (1994). The Event Argu

Kratzer, A. (1995). Stage-Level and Individual-Level Predicates. In G. N. Carlson \& F. J. Pelletier (Eds.), The Generic Book (pp. 125-175). Chicago, London: The University of Chicago Press.

Kratzer, A. (2000). Building Statives. In L.J. Conathan et al. (Eds.), Proceedings of the 26th Annual Meeting of the Berkeley Linguistics Society (pp. 385-399). Berkeley. 
Krifka, M. (1989). Nominal Reference, Temporal Constitution and Quantification in Event Semantics. In R. Bartsch, J. v. Benthem \& P. v. E. Boas (Eds.), Semantics and Contextual Expression (pp. 75-115). R. Bartsch, J. v. Benthem \& P. v. E. Boas (Eds.), Semantics and Contextual Expression (pp. 75-115).
Dordrecht: Foris.

Maienborn, C. (2001). On the Position and Interpretation of Locative Modifiers. Natural Language Semantics, $9(2), 191-240$.

Maienborn, C. (2003a). Die logische Form von Kopula-Sätzen. Berlin: Akademie-Verlag.

Maienborn, C. (2003b). A discourse-based account of Spanish ser/estar. To appear in Linguistics 43(1). ienborn, C. (2004). On the Limits of the Davidsonian Approach: The Case of Copula Sentences. To appear as target article in Theoretical Linguistics.

ilsark, G. L. (1977). Toward an Explanation of Certain Peculiarities of the Existential Construction in English. Linguistic Analysis, 3, 1-29

appear). Do states have Davidsonian arguments? Some empirical considerations. In C. Maienborn \& A. Wöllstein (Eds.), Event Arguments in Syntax, Semantics, and Discourse. Tübingen:

Montmarquet, J. (1980). Whither States? Canadian Journal of Philosophy, 10, 251-256.

Parsons, T. (1990). Events in the Semantics of English. A Study in Subatomic Semantics. Cambridge Mass.: The MIT Press.

Prsons, T. (2000). Underlying States and Time Travel. In J. Higginbotham, F. Pianesi \& A. Varzi (Eds.), Speaking of Events (pp. 81-93). Oxford, New York: Oxford University Press.

Serse

van der Sandt, R. (1992). Presupposition Projection as Anaphora Resolution. Journal of Semantics, 9, 333-377.

Vendler, Z. (1967). Linguistics in Philosopy. Ithaca, New York: Cornell University Press. 